\title{
In vitro inhibition of human blood cholinesterases and protection against chlorpyriphos (organophosphate) by weak anticholinesterase drugs
}

\author{
Ahmed A.J. Mahmood \\ Department of Clinical Pharmacy, College of Pharmacy, University of Mosul, Mosul, Iraq

$\frac{\text { Received } \quad \text { Accepted }}{r .1 \cdot Y \cdot 1 \cdot \quad r \cdot .1, Y \cdot 1 .}$

\begin{abstract}
In vitro inhibition of human plasma and erythrocyte cholinesterase activities by the strong cholinesterase inhibitor chlorpyriphos (organophosphate) and the weak cholinesterase inhibitors (donepezil, metoclopramide, and diphenhydramine) in different concentrations was evaluated. The protective ability of each one of the weak cholinesterase inhibitors alone and with a combination of two of them against the inhibitory action of chlorpyriphos was also detected. The results showed different patterns of inhibition depending on the inhibitor and its concentration when used alone or within a combination. When testing the protective ability, the results differed for each one of the inhibitors and for the combinations, depending on its own ability to bind the cholinesterase. Donepezil showed no ability to protect the enzyme against chlorpyriphos, but caused further increase in the inhibition when used alone or in combination. Diphenhydramine could have affinity to bind the enzyme more than metoclopramide and donepezil when used in combination against chlorpyriphos toxicity, and metoclopramide had higher affinity to inhibit erythrocyte cholinesterase in combination more than diphenhydramine and donepezil. The use of weak cholinesterase inhibitors alone or in combination may reduce the toxicity of organophosphates depending on the inhibitor used, but still not to a significant extent.
\end{abstract}

Keywords: Weak cholinesterases inhibitors, chlorpyriphos, donepezil, metoclopramide, diphenhydramine, protection against organophosphates

الخلاصة

باستخدام الأنابيب الاختبارية تمت دراسة قوة التثبيط لخميرة الكولين استر از في البلازما وكريات الدم الحمر اء إثباء

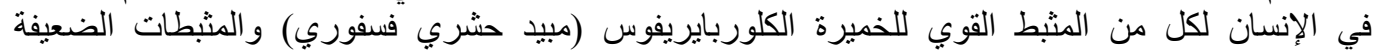

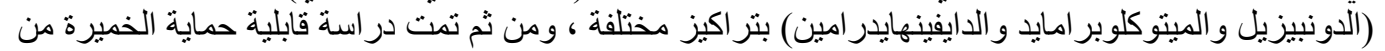

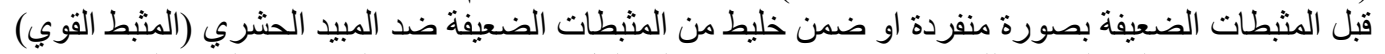

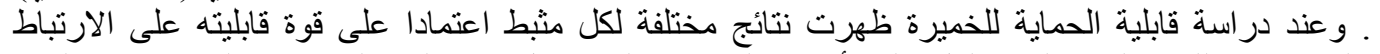

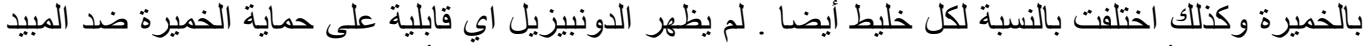

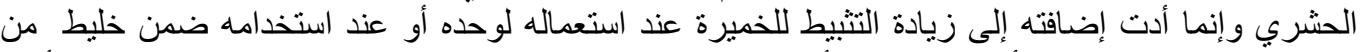

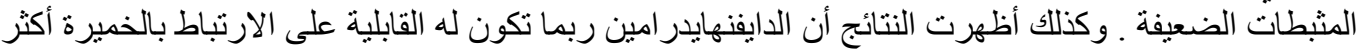

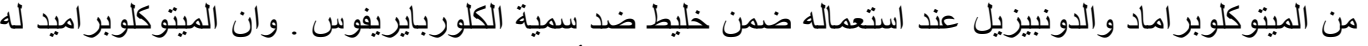

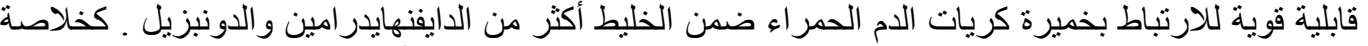

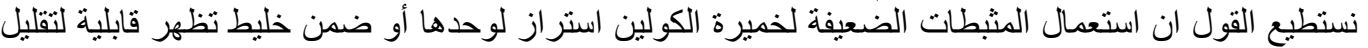
سمية المثبطات القوية (المبيدات الحشرية) اعتمادا على نوعية المثبط ولكن ليس إلى حد يمكننا من استخدامها بصورة عملية .

O rganophosphates (OP) are widely used as insecticides in public health, veterinary practice and agriculture ${ }^{\prime, r}$. The single most 
important mechanism of the toxic action of these insecticides in man and animals is inhibition of acetyl cholinesterase at the nerve terminals, and this causes acetylcholine accumulation that subsequently causes a series of muscarinic, nicotinic and central nervous system effects ${ }^{r, \xi}$. Human blood cholinesterase (ChE) are classified as acetyl cholinesterase (AChE, mainly found in erythrocytes) and butryl cholinesterase (BChE, mainly found in plasma) $\stackrel{r, o}{\circ}$. These enzymes differ in their sensitivity to inhibitors ${ }^{7}$ and therefore, the inhibitors show different toxicities.

The cardinal treatment for organophosphate poisoning includes atropine to counteract the muscarinic signs and symptoms, and oximes to reactivate the inhibited cholinesterases $^{r, r}$. However, the clinical results of administering antidotal therapy for organophosphate poisoning are far from perfect ${ }^{r, r}, \varepsilon$, and there are many experimental trials using other therapeutic and protective agents. Examples of such trials include antihistamine diphenhydramine ${ }^{\gamma, \wedge}$, alpha- $r$-adrenoceptor agonists ${ }^{9}$ and metoclopramide, ${ }^{r}$, ! , , and phenothiazines

Metoclopramide is used clinically as antiemetic agent ${ }^{\top r}$. Other than the antidopaminergic and possible serotonergic effects, metoclopramide has been found to possess anticholinesterase properties ${ }^{1 \cdot, r}$. The drug weakly inhibits cholinesterase activity both in vitro ${ }^{1 r}$ and in vivo'. This protective effect of metoclopramide on the cholinesterase is thought to be of practical usefulness for the treatment of organophosphate poisoning ${ }^{\prime r}$. However, metoclopramide which is a dopamine receptor antagonist was reported to prevent OP poisoning in man (using in vitro system) ' ${ }^{\prime}$ and in chicks both in vitro and in vivo 's. The protective action of metoclopramide is thought to be competition for the active site of the enzyme with the more potent $\mathrm{OP}^{10}$. Metoclopramide inhibited in vitro as well as in vivo the $\mathrm{ChE}$ activity in animals $[1 \leqslant, 17]$. Metoclopramide reduced the toxicity by dichlorvos and daizinon by acting as a protective agent for the $\mathrm{ChE}^{1 \leqslant, 10}$.

Diphenhydramine which is an ethanolamine derivative, nonselective histamine $\mathrm{H}^{\mathrm{l}}$-receptor antagonist, mainly used for allergy symptoms caused by histamine release (anaphylaxis, rhinitis and dermatoses), also can be used for nausea and vertigo and motion sickness ${ }^{1 Y, 1 \wedge, 19}$. The efficacy of diphenhydramine in the prevention and treatment of methomylinduced toxicosis was evaluated in female rats, the results suggest that diphenhydramine could be of therapeutic value in reducing the toxic effects of methomyl ${ }^{r \cdot, r}$. Diphenhydramine inhibits in vitro pseudo cholinesterase (ChE) from several sources (human, rat, or horse plasma). This inhibition is competitive with acetylcholine (ACh) and is reversible, diphenhydramine dose not compete with either OP in inhibiting ChE. ' ${ }^{\prime, r},{ }^{r}$.

Donepezil is an actylchelinesteras inhibitor, mainly used in Alzheimer's disease, it reversibly inhibits actylchelinesteras $^{1 v, 1 \wedge, 19}$. We tried to use it in our study as a protective agent against organophosphate poisoning.

The aim of this study was to evaluate the protective effect of weak ChE inhibitors (metoclopramide, diphenhydramine and donepezil) against the strong inhibitors OP (chlorpyriphos), each one used alone and then as in combination 


\section{Materials and methods}

Subjects The subjects included in this study (male and females, age $r \cdot+/-1$. years) apparently healthy with no history of exposure to anti-ChE insecticides or drugs. Blood samples were collected in a ${ }^{\circ} \mathrm{ml}$ EDTA-treated test tubes then centrifuged (Centurion, UK) at $\mathrm{H} . . \mathrm{rpm}$ for $10 \mathrm{~min}$. The erythrocytes and plasma were separately pooled and kept on ice for $\mathrm{ChE}$ assay.

Electrometric assay of $\mathrm{ChE}$ activity In our work we used the modified electrometric method, validated in human $^{r r, r \xi}$. The reaction mixture in a 1. $\mathrm{ml}$ beaker contained $r \mathrm{ml}$ distilled water, $\cdot r \mathrm{ml}$ plasma or erythrocytes and $r \mathrm{ml} \mathrm{pH} \wedge$.) barbital-phosphate buffer $^{{ }^{\circ}}$. The $\mathrm{pH}$ of the mixture $\left.(\mathrm{pH})^{\prime}\right)$ was measured with glass electrode using $\mathrm{pH}$ meter (Hanna Instruments, Romania), then $\because$ l $\mathrm{ml}$ of aqueous solution of acetylthicholine ( $\vee .0 \%$ ) was added to the reaction mixture which was incubated at $r v^{\circ} \mathrm{C}$ in water bath (Shaker bath ${ }^{\circ} \mathrm{BS} r \cdot$, UK) for $r \cdot \min$. At the end of the incubation period, the $\mathrm{pH}$ of the reaction mixture $\left(\mathrm{pH}^{\mathrm{r}}\right)$ was measured. The enzyme activity was calculated as follows:

ChE activity $(\Delta p H / r \cdot \min )=.\left(p H^{\prime}-\right.$ $p H$ ) $-\Delta p H$ of blank

The blank contained no blood aliquot. The barbital-phosphate buffer solution consist of $1 . r \leqslant \mathrm{~g}$ sodium barbital (BDH), $\cdot 17 r \mathrm{~g}$ potassium dihydrogen phosphate (Merck, Germany), and ro.v g sodium chloride $(\mathrm{BDH})$ dissolved in one liter distilled water ${ }^{r, r o}$. The $\mathrm{pH}$ of the buffer was adjusted to $\Lambda_{\text {.) }}$ with $\mathrm{IN}$ $\mathrm{HCl}$.

In vitro ChE inhibition by the inhibitors Plasma and erythrocyte samples were collected from healthy volunteers. Different drug concentrations were prepared then they were individually added in a volume of $.1 \mathrm{ml}$ to the reaction mixture to obtain final concentrations as follows:

$$
\begin{aligned}
& \text { chlorpyriphos: }\{\mu \mathrm{M} \\
& \text { metoclopramide: }{ }^{\circ}, r_{0} \text { and } 1 r^{\circ} \\
& \mu \mathrm{M} \\
& \text { diphenhydramine: } 1 \cdots, 0 \text {, and ro } \\
& \mu \mathrm{M}
\end{aligned}
$$$$
\text { donepezil: } 1 \cdots \text { and ro } \mu \mathrm{M}
$$

the concentrations of chlorpyriphos and the drugs used in the present study were obtained from preliminary experiments to validate the experimental concentrations. The inhibitors were prepared in distilled water and individually added in a. l $\mathrm{ml}$ to the reaction mixture of the plasma and erythrocytes. The reaction mixture containing inhibitors was incubated at $r V{ }^{\circ} \mathrm{C}$ for 1 . $\min$. Thereafter, the residual ChE activity in mixture was measured"'. The $\%$ of enzyme inhibition was calculated as follows:\% ChE inhibition $=[C h E$ activity (without inhibitors)-ChE activity (with inhibitors)/ChE activity (without inhibitors) $] X^{\prime}$..

In vitro $\mathrm{ChE}$ inhibition by the weak inhibitors and the strong inhibitor (chlorpyriphos)

Aliquots of the same plasma and erythrocyte samples used in the previous experiment were used here and the same concentrations of inhibitors were also used, chlorpyriphos was diluted with distilled water and added in a volume of $.1 \mathrm{ml}$ to the reaction mixture to obtain a final concentration of $\varepsilon \mu \mathrm{M}$, each drug concentration mentioned above was added to the reaction mixture $(\because) \mathrm{ml}) \perp \cdot$ min before the chlorpyriphos addition "', which was then incubated at ${ }^{\mathrm{r}}{ }^{\circ} \mathrm{C}$ for $1 . \mathrm{min}$ before measuring $\mathrm{ChE}$ activities 
and percent of enzyme inhibition as described above.

In vitro ChE inhibition by a
combination of weak ChE
inhibitorsnd then by the same
combination with the strong
inhibitor (chlorpyriphos)
In another set of experiment other plasma and erythrocyte samples used and the drugs were used here as a combination of inhibitors in different concentrations as follows:

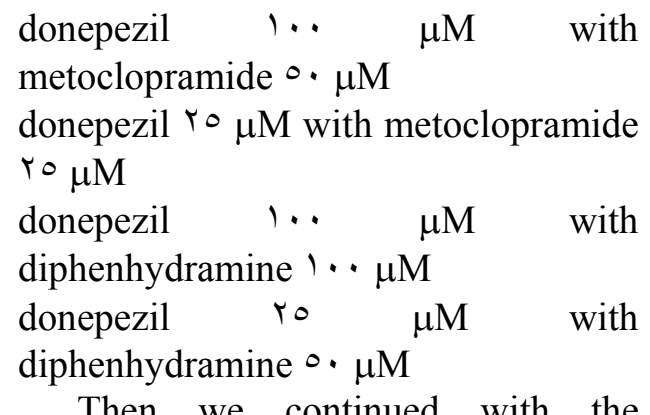
following inhibitors and concentrations metoclopramide $0 . \mu \mathrm{M}$ with diphenhydramine $1 \cdots \mu \mathrm{M}$

metoclopramide ro $\mu \mathrm{M}$ with diphenhydramine $0 \cdot \mu \mathrm{M}$

metoclopramide ro $\mu \mathrm{M}$ with diphenhydramine ro $\mu \mathrm{M}$

metoclopramide IY.o $\mu \mathrm{M}$ with diphenhydramine $0 \cdot \mu \mathrm{M}$

metoclopramide IY.o $\mu \mathrm{M}$ with diphenhydramine ro $\mu \mathrm{M}$

Each combination mentioned above was added to the reaction mixture $(\cdot 1 \mathrm{ml})$ (both weak inhibitors added at the same time), which was then incubated at $r v{ }^{\circ} \mathrm{C}$ for $1 \cdot \min$ before measuring $\mathrm{ChE}$ activities and percent of enzyme inhibition as described in the previous experiment.

Then the same plasma and erythrocyte samples used in this experiment and the same combination of inhibitors mentioned above were also used in the same way of addition and incubation. Chlorpyriphos was then added in a volume of $.1 \mathrm{ml}$ to the reaction mixture to obtain a final concentration of $\varepsilon \mu \mathrm{M}$ (chlorpyriphos was diluted and used as described in the previous experiment), which was then incubated at $\mathrm{rV}{ }^{\circ} \mathrm{C}$ for $1 \cdot \min$ before measuring $\mathrm{ChE}$ activities and percent of enzyme inhibition as described in the previous experiment.

\section{Statistical Analysis}

The data were subjected to analysis of variance followed by the least of significant difference test ${ }^{r}$. Paired Student's t-test was used for comparing the means of $r$ groups ${ }^{r Y}$. The level of significance was at $\mathrm{P}<\bullet . \bullet$.

\section{Results}

The in vitro inhibition of plasma and erythrocyte ChE activities by the strong ChE inhibitor (chlorpyriphos) $\varepsilon$ $\mu \mathrm{M}$ and weak ChE inhibitors (donepezil, metoclopramide, and diphenhydramine) in different concentrations, and then each one of the weak $\mathrm{ChE}$ inhibitors with the strong one was detected and the results are shown in Table '.

Tables $r$ and $r$ represent in vitro inhibition of plasma and erythrocyte cholinesterase activities by a combination of weak $\mathrm{ChE}$ inhibitors (donepezil $\quad$.., ro, ro M with metoclopramide $\bullet \cdot, \quad r \circ \mu \mathrm{M}$ and then donepezil $\quad$.., $\quad$ $\bullet \mu \mathrm{M}$ with diphenhydramine $1 \cdots, 0 \cdot \mu \mathrm{M}$ ) each combination alone and then with the strong $\mathrm{ChE}$ inhibitor (chlorpyriphos) (Table $r$ ), and the combination of (metoclopramide $\bullet \cdot, \quad r \circ \mu \mathrm{M}$ and Ir. $0 \mu \mathrm{M}$ with diphenhydramine $1 .$. $\bullet \cdot \mu \mathrm{M}$ and $\mathrm{r}^{\circ} \mu \mathrm{M}$ ) each combination as alone and then with the strong $\mathrm{ChE}$ inhibitor (chlorpyriphos) (Table ${ }^{\mathrm{T}}$ ).

In order to compare the combinations, Figure, and $r$ represent $\%$ inhibition of plasma and erythrocyte cholinesterase of each combination used in this experiment as alone and then with the strong $\mathrm{ChE}$ inhibitor (chlorpyriph) 
Table 1: In vitro inhibition of human plasma and erythrocyte cholinesterase activities by numbers of $\mathrm{ChE}$ inhibitors and their effect on ChEs inhibition by the strong inhibitor (chlorpyriphos)

\begin{tabular}{|c|c|c|c|c|}
\hline \multirow[b]{2}{*}{ Inhibitors $(\mu \mathrm{M})$} & \multicolumn{2}{|c|}{ Plasma ChE } & \multicolumn{2}{|c|}{ Erythrocyte ChE } \\
\hline & $\Delta \mathrm{pH} / r \cdot \min$ & $\begin{array}{c}\% \\
\text { Inhibition } \\
\end{array}$ & $\Delta \mathrm{pH} / r \cdot \min$ & $\begin{array}{c}\% \\
\text { Inhibition } \\
\end{array}$ \\
\hline$\cdot \mu \mathrm{M}$ & $1.17 \pm \cdot .94$ & . & $\cdot V \varepsilon_{ \pm} \cdot r \cdot V^{a}$ & . \\
\hline chlorpyriphos $\leqslant \mu \mathrm{M}^{*}$ & $\because \cdot r_{ \pm} \cdot . \cdot 1 r^{\mathrm{a}}$ & $9 \leq . \vee$. & $\cdot 90 \pm \cdot . r)^{\mathrm{a}}$ & rl. $\varepsilon$. \\
\hline donepezil $\cdots \mu \mathrm{M}^{*}$ & $\cdot r \Delta_{ \pm} \cdot r \mid r a b$ & $7 \wedge .71$ & $\because \cdot 1 \pm \cdot .1 \leq \mathrm{ab}$ & qV.r^ \\
\hline $\begin{array}{l}\text { donepezil } 1 \cdots \mu \mathrm{M} \text { before } \\
\text { chlorpyriphos } \leqslant \mu \mathrm{M}\end{array}$ & $\because \cdot r_{ \pm} \cdot r \mid r^{a}$ & $9 \wedge . Y 1$ & $\because \cdots \pm \cdot \cdots$ a b & $1 \ldots$ \\
\hline donepezil ro $\mu \mathrm{M}^{*}$ & $\cdot . T \pm \cdot \cdot \cdot 1 \leq a b$ & $\leq \varepsilon . \wedge \varepsilon$ & $\because \cdot r_{ \pm} \cdot r \mid r$ ab & N.r. \\
\hline $\begin{array}{l}\text { donepezil Yo } \mu \mathrm{M} \text { before } \\
\text { chlorpyriphos } \Sigma \mu \mathrm{M}\end{array}$ & $\because \cdots r_{ \pm} \cdot \cdot^{\mathrm{a}}$ & $99 . \vee r$ & $\because \cdots \pm \cdot \cdots^{a b}$ & $1 \ldots$ \\
\hline metoclopramidee $\bullet \cdot \mu \mathrm{M}^{*}$ & $\because v_{ \pm} \cdot \ldots v^{a}$ & $9 \leq . \Gamma$. & $.{ }^{\mu} \cdot \pm \cdot .00 \mathrm{ab}$ & $V Y . V$. \\
\hline $\begin{array}{l}\text { metoclopramide } 0 \cdot \mu \mathrm{M}^{\ddagger} \\
\text { before chlorpyriphos } \leqslant \mu \mathrm{M}\end{array}$ & $\because \cdot r \pm \cdot . r l^{a}$ & $9 \wedge . \vee 7$ & $\cdot r r_{ \pm} \cdot .1 r \leq b$ & $0 \leqslant .99$ \\
\hline metoclopramide $r^{\circ} \mu \mathrm{M}^{*}$ & $\cdot . r 1 \pm \cdot . \cdot \cdot{ }^{a b}$ & Ar.q. & $1, r_{ \pm} \cdot .1 r^{a b}$ & T.Y. \\
\hline $\begin{array}{l}\text { metoclopramide } \text { To } \mu \mathrm{M}^{*} \\
\text { before chlorpyriphos } \leqslant \mu \mathrm{M}\end{array}$ & $\because .0_{ \pm} \cdot . r \Delta^{a}$ & $97 . Y \wedge$ & $.07_{ \pm} \cdot . \cdot \mathrm{roa}^{\mathrm{a}}$ & $r \cdot . V^{\prime}$ \\
\hline diphenhydramine $1 \cdots \mu \mathrm{M}^{*}$ & $\left.\cdot r \varepsilon_{ \pm} \cdot . r\right)$ a b & $7 V . \vee 9$ & $1 . r_{ \pm} \cdot .9 \Lambda^{b}$ & V.YI \\
\hline $\begin{array}{l}\text { diphenhydramine } 1 \cdots \mu \mathrm{M}^{\ddagger} \\
\text { before chlorpyriphos } \leqslant \mu \mathrm{M}\end{array}$ & $\because \cdots \pm \cdot,{ }^{\text {a }}$ & $1 \ldots$ & $.01 \pm \cdot \ldots v^{a}$ & YV.AT \\
\hline diphenhydramine ${ }^{\circ} \cdot \mu \mathrm{M}^{*}$ & $.0 r_{ \pm} . .0 r^{a b}$ & $0 . .$. & $\cdot r r_{ \pm} \cdot r r_{1}$ ab & $\leqslant 9.49$ \\
\hline $\begin{array}{l}\text { diphenhydramine }{ }^{0} \cdot \mu \mathrm{M}^{\ddagger} \\
\text { before chlorpyriphos } \leqslant \mu \mathrm{M}\end{array}$ & $\because \cdots \pm \cdot \ldots{ }^{a}$ & $1 \ldots$ & $. r r_{ \pm} \cdot . \cdot 1 \leq a b$ & $7 V .1 \leq$ \\
\hline
\end{tabular}

$\mathrm{N}=\mathrm{r} /$ concentration groups.

Cholinesterase inhibition was detected after $1 \cdot \min$ incubation of the sample with ChE inhibitors. \$ weak ChE inhibitors was added to the reaction mixture $1 \cdot$ min before the strong ChE inhibitors (chlorpyriphos) addition.

a Significantly different from their respective control $(\cdot)$ group, $\mathrm{P}<\cdot . \bullet$

b Significantly different from the strong ChE inhibitors (chlorpyriphos) $(\varepsilon \mu \mathrm{M}), \mathrm{P}<\bullet^{.} \bullet$ 
Table r: In vitro inhibition of human plasma and erythrocyte cholinesterase activities by a combination of weak $\mathrm{ChE}$ inhibitors (donepezil with metoclopramide and then donepezil with diphenhydramine) and their effect on ChEs inhibition by the strong inhibitor (chlorpyriphos)

\begin{tabular}{|c|c|c|c|c|}
\hline \multirow{2}{*}{ Inhibitors $(\mu \mathbf{M})$} & \multicolumn{2}{|c|}{ Plasma ChE } & \multicolumn{2}{|c|}{ Erythrocyte ChE } \\
\hline & $\Delta \mathrm{pH} / r \cdot \min$ & $\begin{array}{c}\% \\
\text { Inhibition } \\
\end{array}$ & $\Delta \mathbf{p H} / r \cdot \min$ & $\begin{array}{c}\% \\
\text { Inhibition } \\
\end{array}$ \\
\hline$\cdot \mu \mathrm{M}$ & $1.1 r_{ \pm} \cdot . \cdot \lambda r$ & · & $\cdot 9 \leqslant \pm \cdot . r 10$ & • \\
\hline $\begin{array}{l}\text { donepezil } \because \cdots \mu \mathrm{M}+{ }^{*} \\
\text { metoclopramide } \odot \cdot \mu \mathrm{M}\end{array}$ & $.1 v_{ \pm} \cdot . \cdot 1 \leq a b$ & $\Lambda \varepsilon . \cdot \varepsilon$ & $\because r_{ \pm} \cdot \ldots r^{a b}$ & $\wedge \wedge . \wedge 9$ \\
\hline $\begin{array}{l}\text { donepezil } 1 \cdots \mu \mathrm{M}+\stackrel{\ddagger}{ } \\
\text { metoclopramide } \odot \cdot \mu \mathrm{M} \text { before } \\
\text { chlorpyriphos } \leqslant \mu \mathrm{M}\end{array}$ & $\because \cdot \wedge_{ \pm} \cdot \cdot r^{\prime}{ }^{a}$ & 94.97 & $\because \cdot \varepsilon_{ \pm} \cdot . \cdot 1 \leq a b$ & 91.94 \\
\hline $\begin{array}{l}\text { donepezil }{ }^{\circ} \mu \mathrm{M}+{ }^{*} \\
\text { metoclopramide }{ }^{\circ} \mu \mathrm{M}\end{array}$ & $\cdot r \varepsilon_{ \pm} \cdot \ldots$ ab & $V V . \leqslant V$ & $\because \cdot \Upsilon_{ \pm} \cdot . r \wedge a b$ & $\wedge \vee . \wedge \Lambda$ \\
\hline $\begin{array}{l}\text { donepezil ro } \mu \mathrm{M}+\stackrel{+}{ } \\
\text { metoclopramide } r^{\circ} \mu \mathrm{M} \text { before } \\
\text { chlorpyriphos } \varepsilon \mu \mathrm{M}\end{array}$ & $\cdot 1 \cdot \pm \cdot . \cdot 1 \varepsilon^{a}$ & $9 \cdot .71$ & $\because \cdot \varepsilon_{ \pm} \cdot \ldots v^{a b}$ & 94.94 \\
\hline $\begin{array}{l}\text { donepezil } 1 \cdots \mu \mathrm{M}+{ }^{*} \\
\text { diphenhydramine } 1 \cdots \mu \mathrm{M}\end{array}$ & $\cdot r r_{ \pm} \cdot . r \wedge^{a b}$ & $\vee 9.91$ & $\because \cdot \pm \cdot . v^{a b}$ & 91.01 \\
\hline $\begin{array}{l}\text { donepezil } 1 \cdots \mu \mathrm{M}+* \\
\text { diphenhydramine } 1 \cdots \mu \mathrm{M} \\
\text { before chlorpyriphos } \leqslant \mu \mathrm{M}\end{array}$ & $\because \cdot r_{ \pm} \cdot . r r^{a}$ & 91.79 & $\because \cdots \pm \cdot \cdots{ }^{a b}$ & $1 \ldots$ \\
\hline $\begin{array}{l}\text { donepezil ro } \mu \mathrm{M}+{ }^{*} \\
\text { diphenhydramine } \odot \cdot \mu \mathrm{M}\end{array}$ & $. \varepsilon \Gamma_{ \pm} \cdot . . \circ \gamma^{a b}$ & $T Y \leq 0$ & $\because \cdot r_{ \pm} \cdot . \cdot 1 \leq a b$ & $q \leq . \cdot r$ \\
\hline $\begin{array}{l}\text { donepezil Yo } \mu \mathrm{M}+{ }^{\ddagger} \\
\text { diphenhydramine } \diamond \cdot \mu \mathrm{M} \\
\text { before chlorpyriphos } \leqslant \mu \mathrm{M}\end{array}$ & $\because \cdot \varepsilon_{ \pm} \cdot . \cdot 1 \varepsilon^{a}$ & 97.01 & $\because \cdots \pm \cdot \cdots^{a b}$ & $1 \ldots$ \\
\hline
\end{tabular}

$\mathrm{N}=\mathrm{r} /$ concentration groups.

*holinesterase inhibition was detected after $1 \cdot \min$ incubation of the sample with the mixture of weak ChE inhibitors.

\$ The mixture of weak $\mathrm{ChE}$ inhibitors was added to the reaction mixture $1 \cdot \min$ before the strong $\mathrm{ChE}$ inhibitors (chlorpyriphos) addition.

a Significantly different from their respective control $(\cdot)$ group, $\mathrm{P}<\cdot . \bullet$

b Significantly different from the strong ChE inhibitors (chlorpyriphos) $(\varepsilon \mu \mathrm{M}), \mathrm{P}<\bullet^{\circ} \bullet$ 
Table r: In vitro inhibition of human plasma and erythrocyte cholinesterase activities by a combination of weak $\mathrm{ChE}$ inhibitors (metoclopramide with diphenhydramine ) and their effect on ChEs inhibition by the strong inhibitor (chlorpyriphos)

\begin{tabular}{|c|c|c|c|c|}
\hline \multirow{2}{*}{ Inhibitors $(\mu \mathrm{M})$} & \multicolumn{2}{|c|}{ Plasma ChE } & \multicolumn{2}{|c|}{ Erythrocyte ChE } \\
\hline & $\Delta \mathrm{pH} / r \cdot \min$ & $\begin{array}{c}\% \\
\text { Inhibition }\end{array}$ & $\Delta \mathrm{pH} / r \cdot \min$ & $\begin{array}{c}\% \\
\text { Inhibition }\end{array}$ \\
\hline$\cdot \mu \mathrm{M}$ & $1.1 V_{ \pm} \cdot .1 r \varepsilon$ & · & $.0 \leqslant \pm \cdot . r Y \leqslant$ & • \\
\hline $\begin{array}{l}\text { metoclopramide } 0 \cdot \mu \mathrm{M}+{ }^{*} \\
\text { diphenhydramine } 1 \cdots \mu \mathrm{M}\end{array}$ & $\because \cdot{ }^{9} \pm \cdot .{ }^{a}$ & $94.1 \leq$ & $\left.\cdot r q_{ \pm} \cdot .9\right)^{b}$ & $1 T . \Sigma T$ \\
\hline $\begin{array}{l}\text { metoclopramide } 0 \cdot \mu \mathrm{M}+{ }^{\ddagger} \\
\text { diphenhydramine } 1 \cdots \mu \mathrm{M} \\
\text { before chlorpyriphos } \leqslant \mu \mathrm{M}\end{array}$ & $\because \cdot 1 \pm \cdot . \cdot 1 \varepsilon^{a}$ & 99.11 & $\because 1 r_{ \pm} \cdot . \cdot \leqslant q a b$ & $71 . \leqslant 9$ \\
\hline $\begin{array}{l}\text { metoclopramide } \text { ro } \mu \mathrm{M}+{ }^{*} \\
\text { diphenhydramine } \odot \cdot \mu \mathrm{M}\end{array}$ & $\cdot \mid r_{ \pm} \cdot . \cdot r^{a}$ & 19.97 & $\cdot r r_{ \pm} \cdot \ldots v^{a b}$ & $r$ r.As \\
\hline $\begin{array}{l}\text { metoclopramide } r^{\circ} \mu \mathrm{M}+{ }^{\ddagger} \\
\text { diphenhydramine } 0 \cdot \mu \mathrm{M} \\
\text { before chlorpyriphos } \leqslant \mu \mathrm{M}\end{array}$ & $\because \cdot \varepsilon_{ \pm} \cdot \ldots v^{a}$ & $97.9 \leq$ & $\because V_{ \pm} \cdot . r \wedge^{a b}$ & $\leqslant 9 . r_{0}$ \\
\hline $\begin{array}{l}\text { metoclopramide } r^{\circ} \mu \mathrm{M}+{ }^{*} \\
\text { diphenhydramine } r^{\circ} \mu \mathrm{M}\end{array}$ & $\because Y_{ \pm} \pm \cdot \cdot 1 \leq \mathrm{ab}$ & Ar. $T \varepsilon$ & $\cdot 0 \cdot \pm \cdot . \cdot r \Lambda$ & YA.OV \\
\hline $\begin{array}{l}\text { metoclopramide } r^{\circ} \mu \mathrm{M}+{ }^{\ddagger} \\
\text { diphenhydramine } r^{\circ} \mu \mathrm{M} \\
\text { before chlorpyriphos } \leqslant \mu \mathrm{M}\end{array}$ & $\because \cdot 9 \pm \cdot .9 r^{a}$ & 94.91 & $.00 \pm \cdot . \cdot 1 r$ & rY.IE \\
\hline $\begin{array}{l}\text { metoclopramide I }{ }^{\circ}{ }^{\circ} \mu \mathrm{M}+{ }^{*} \\
\text { diphenhydramine } \odot \cdot \mu \mathrm{M}\end{array}$ & $\because \Delta \wedge_{ \pm} \cdot . v^{a b}$ & or. $\leqslant 1$ & $\because T V_{ \pm} \cdot . l r \cdot a b$ & $\leqslant .99$ \\
\hline $\begin{array}{l}\text { metoclopramide } I Y \cdot{ }^{\circ} \mu \mathrm{M}+\ddagger \\
\text { diphenhydramine }{ }^{\ddagger} \cdot \mu \mathrm{M} \\
\text { before chlorpyriphos } \leqslant \mu \mathrm{M}\end{array}$ & $\because \cdot r_{ \pm} \cdot \ldots v^{a}$ & $9 \vee .94$ & $\cdot r \Lambda_{ \pm} \cdot r v \Delta^{b}$ & $\leqslant \nearrow . \leqslant r$ \\
\hline $\begin{array}{l}\text { metoclopramide I r.॰ } \mu \mathrm{M}+{ }^{*} \\
\text { diphenhydramine r॰ } \mu \mathrm{M}\end{array}$ & $\cdot r \Lambda_{ \pm} \cdot . \cdot 1 \leq \mathrm{ab}$ & $\vee \neg . \wedge T$ & $\cdot .00 \pm \cdot . \cdot 1 \leqslant a$ & $17.7 V$ \\
\hline $\begin{array}{l}\text { metoclopramide } 1 \text { r.॰ } \mu \mathrm{M}+{ }^{\ddagger} \\
\text { diphenhydramine }{ }^{\circ} \mu \mathrm{M} \\
\text { before chlorpyriphos } \leqslant \mu \mathrm{M}\end{array}$ & $\because \cdot \varepsilon_{ \pm} \cdot . \cdots$ a & 97.79 & $\cdot\left\{V_{ \pm} \cdot . \cdot r\right)^{a}$ & Y9.00 \\
\hline
\end{tabular}

$\mathrm{N}=r$ / concentration groups.

Cholinesterase inhibition was detected after $1 \cdot \min$ incubation of the sample with the mixture of weak ChE inhibitors.

\$ The mixture of weak $\mathrm{ChE}$ inhibitors was added to the reaction mixture $1 \cdot \min$ before the strong $\mathrm{ChE}$ inhibitors (chlorpyriphos) addition.

a Significantly different from their respective control $(\cdot)$ group, $\mathrm{P}<\cdot . \bullet$

b Significantly different from the strong ChE inhibitors (chlorpyriphos) $(\varepsilon \mu \mathrm{M}), \mathrm{P}<\cdot . \bullet$ 


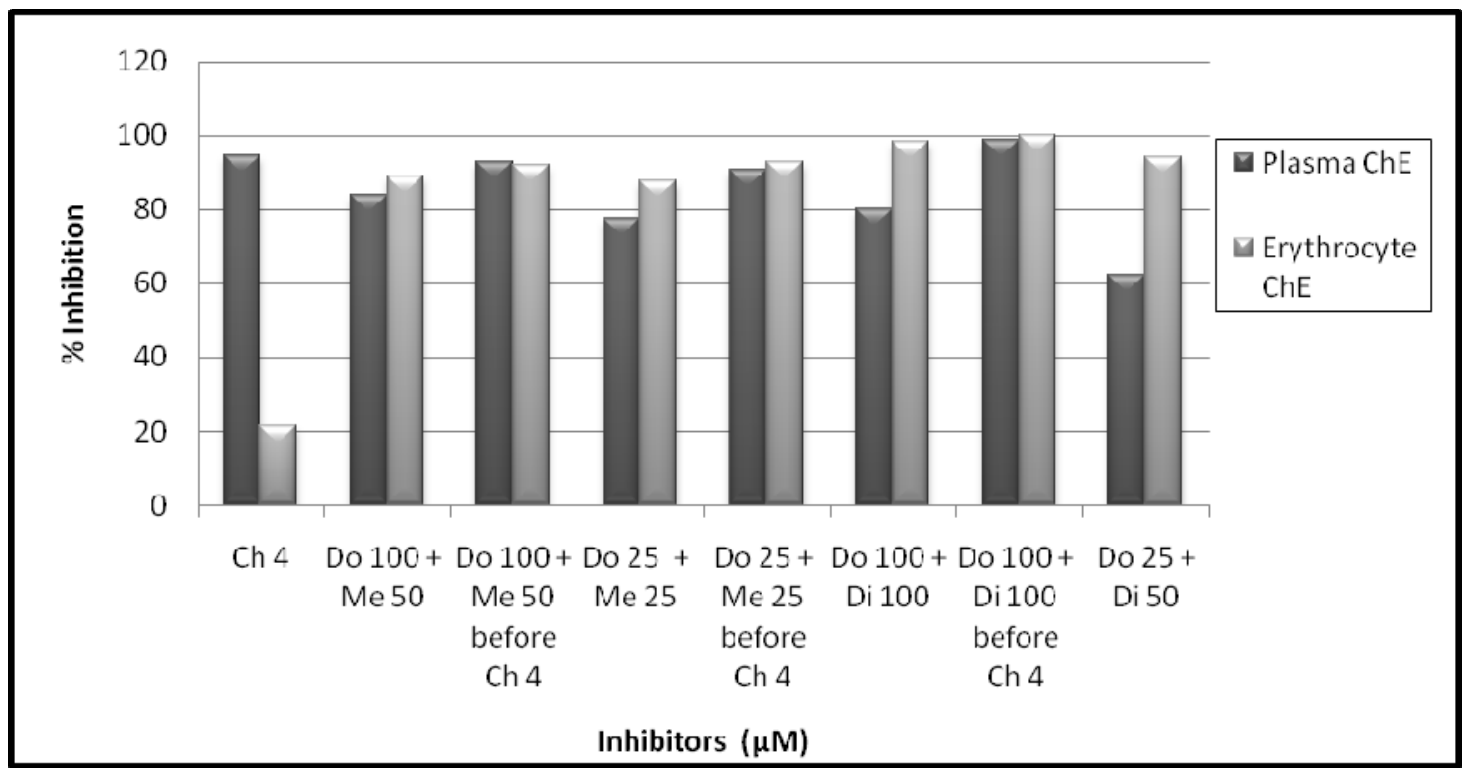

Figure 1: \% Inhibition of human plasma and erythrocyte cholinesterase by a combination of weak $\mathrm{ChE}$ inhibitors donepezil (Do) with metoclopramide (Me) and then donepezil (Do) with diphenhydramine (Di ) and then each combination with the strong ChE inhibitor chlorpyriphos (Ch).

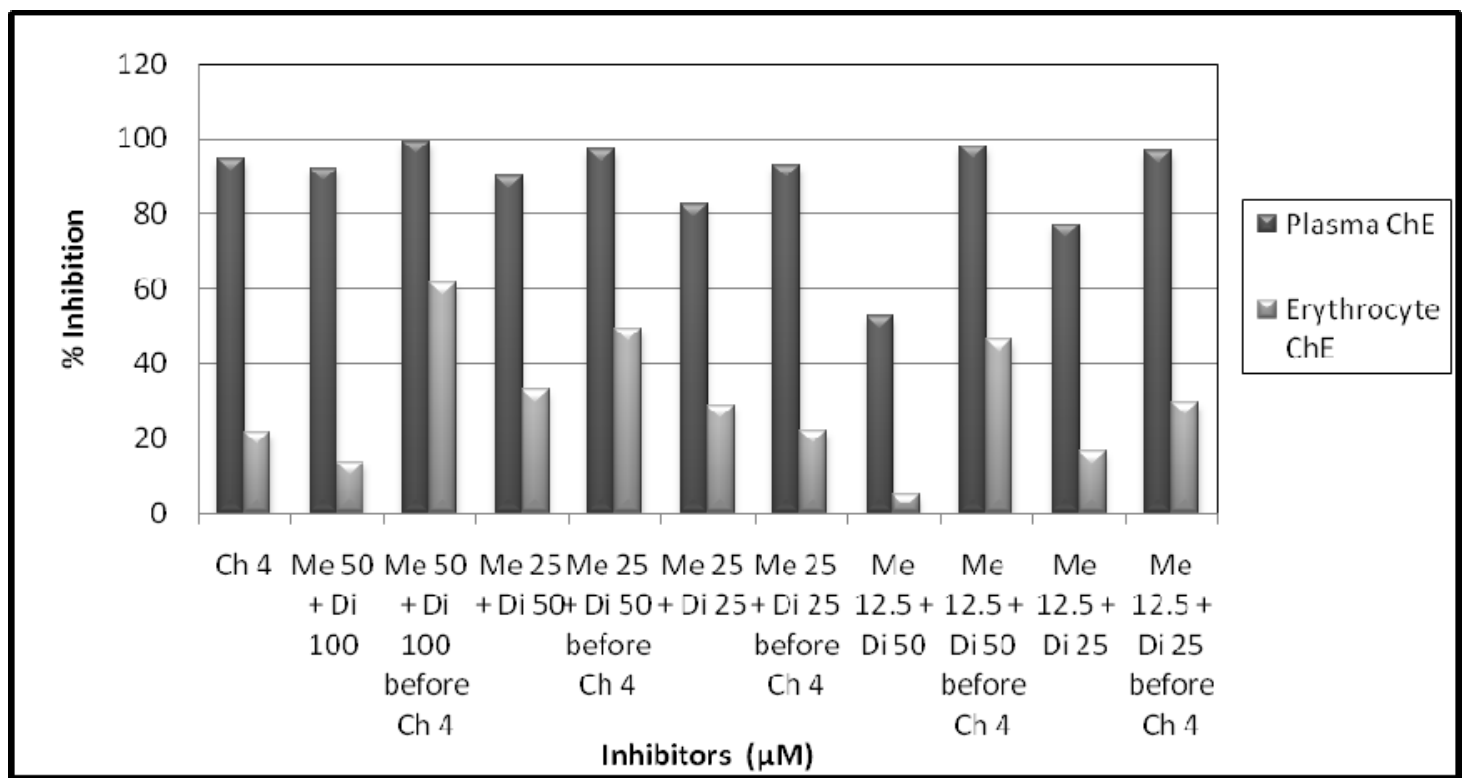

Figure $r$ : \% Inhibition of human plasma and erythrocyte cholinesterase by a combination of weak ChE inhibitors metoclopramide (Me), diphenhydramine (Di ) and then each combination with the strong $\mathrm{ChE}$ inhibitor chlorpyriphos $(\mathrm{Ch})$. 


\section{Discussion}

In vitro ChE inhibition system is used to evaluate $\mathrm{ChE}$ inhibiting potential of chemicals with binding affinities to $\mathrm{ChE}{ }^{r \wedge, r q}$. It was found that there was a good correlation between $\mathrm{ChE}$ inhibitions in vitro and in vivor", and usually in vitro ChE inhibition assists in the clinical interpretation of pesticide intoxication ${ }^{7,}$, .

As expected, chlorpyriphos, which is an OP, caused ChE inhibition in the plasma and erythrocyte (in vitro). This is in correlation with previous in vitro studies in human ${ }^{r r, r \xi}$. In the present study, chlorpyriphos inhibited plasma ChE activity more than erythrocyte ChE. This effect has been reported by others ${ }^{\text {ro }}$. It was attributed to the inherent activity of the particular OP; it is well known that OP may vary in their inhibition potentials of tissue $\mathrm{ChE}^{r, r r}$.

Weak or reversible ChE inhibitors can reduce or prevent toxicity of $\mathrm{OP}^{\prime}$, and also prevent further increase in ChE inhibition caused by $\mathrm{OP}^{r, r \varepsilon}$. However, weak ChE inhibitors given after OP, might increase the toxicity of the latter compound ${ }^{\text {}}$, this is why we use the weak inhibitor before the strong one rather than after it. These weak inhibitors increased $\mathrm{ChE}$ inhibition in subjects already exposed to anti $\mathrm{ChE}$, the weak inhibitor may inhibit a small fraction of residual ChE activity or they do not bind the same sites that bind with OP resulting in maximum toxicity ${ }^{r}$.

All the drugs used in this study are of known ability to inhibit the ChE in varying degrees, metoclopramide and diphenhydramine (as a weak inhibitors) both have been tested as protective agent against $\mathrm{OP}$ poisoning both in vitro and in vivo ${ }^{\prime}, r \cdot r$. Donepezil, a known anticholenesterase drug ${ }^{\text {ro }}$, no previous study poses its ability to protect the $\mathrm{ChE}$ against $\mathrm{OP}$ poisoning. In this study we use each of them as ChE inhibitor and as a protector against OP, and then we combined both of them to find whether the combination will protect or further increase the OP ChE inhibition.

We found that all the weak $\mathrm{ChE}$ inhibitors showed different levels of inhibition of plasma $\mathrm{ChE}$ but all of them increased OP $\mathrm{ChE}$ inhibition when given before it (Table 1). The erythrocyte $\mathrm{ChE}$ showed a similar result (Table 1) except that metoclopramide $0 \cdot \mu \mathrm{M}$ which reduced the ability of its toxicity from ( $\mathrm{V} . \mathrm{V} \%)$ to $(0 \leqslant .9 \%)$ when given before the OP (chlorpyriphos), but still higher than OP ChE inhibition (Table 1). Also metoclopramide $r \circ \mu \mathrm{M}$ showed further decrease in OP ChE inhibition to lower than the normal inhibitory level ( $($ ).$\leqslant \%)$ reduced to $(Y \cdot . \vee \%)$ (not statistically significant), but it is still higher than its normal inhibitory level $(\vee . Y) \%$ ) (i.e. Increase its toxicity and decrease OP ChE inhibition) (Table I). Diphenhydramine $1 \cdots \mu \mathrm{M}$ showed low level of erythrocyte $\mathrm{ChE}$ inhibition alone but still increased OP $\mathrm{ChE}$ inhibition (Table 1), whereas diphenhydramine $0 \cdot \mu \mathrm{M}$ show high level of increasing ChE inhibition as alone and with OP but still lower than the other weak ChE inhibitors (Table 1).

The combinations showed slightly different results, donepezil combination with other weak ChE inhibitor show maximal increase in the toxicity for both plasma and erythrocyte $\mathrm{ChE}$ (increase both its own alone and the OP \% of inhibition) (Table $r$, Figure 1$)$. Although the two combinations (donepezil $\quad \cdots \mu \mu \mathrm{M}$ with metoclopramide $0 \cdot \mu \mathrm{M}$, donepezil ro $\mu \mathrm{M}$ with metoclopramide ro $\mu \mathrm{M}$ ) showed increase in their own toxicity alone when used with the OP but still lower than (yet not statistically significant) the $\%$ of plasma $\mathrm{ChE}$ 
inhibition of OP alone (Table $r$, Figure 1). This result probably refers to the effect of metoclopramide because no such effect have been seen with the same donepezil concentration alone or with the same concentration when used as combination with the diphenhydramine (Table r, Figure '). However, metoclopramide affect the erythrocyte $\mathrm{ChE}$ more than the plasma ChE (Table ', Table r, Figure r) ${ }^{1, r \varepsilon}$, so such effect could be referred to the effect of the two weak ChE inhibitors (donepezil and metoclopramide) as a combination when used together in this concentrations.

The combinations containing metoclopramide and diphenhydramine showed different results, $\%$ of inhibition of plasma $\mathrm{ChE}$ showed the same result of the previous combinations (i.e. Increase in $\%$ of its inhibition alone and that of OP plasma ChE) (Table $r$, Figure $r$ ). However, in case of erythrocyte ChE showed different way of inhibition, all of the combinations showed reduction of $\%$ of inhibition of one of its component when used alone (i.e. the weak $\mathrm{ChE}$ inhibitors protect erythrocyte $\mathrm{ChE}$ from each other to produce what we call it a mean of $\%$ of inhibition which is between the $\%$ of erythrocyte inhibition of the two weak inhibitors when used alone in different degree of inhibition regarding each combination) (Table r, Figure r). Such protection can be caused by the competition of the two ChE inhibitors on the enzyme molecule but in different degrees of affinity for each concentration, this is why we found different abilities of lowering the $\%$ of inhibition for each concentration used alone and when used as a combination with other concentrations of the other weak $\mathrm{ChE}$ inhibitors (Table $r$, Figure $r$ ).
When all the combinations were used with the strong $\mathrm{ChE}$ inhibitor (chlorpyriphos) they showed increase in their own toxicity compared to its use alone and higher than that the $\%$ of inhibition of OP alone, but still not very high like those in the combinations containing the donepezil (Table r, Figure r). This could be caused by their abilities of inhibition of the enzyme being lower than that of donepezil (i.e. the selectivity of the donepezil is higher). Although the two combinations (that containing diphenhydramine ro $\mu \mathrm{M}$ ) show the lowest \% of erythrocyte ChE inhibition when given before the OP (chlorpyriphos) (slightly above the \% of inhibition of OP alone), but still not considered as protective since these could not reduce the $\%$ of inhibition below the that of OP alone.

Suggesting that the diphenhydramine could have affinity to bind the enzyme more than metoclopramide and donepezil when used within a combination with other weak ChE against the OP toxicity (chlorpyriphos), and the metoclopramide have high affinity than diphenhydramine to bind the erythrocyte $\mathrm{ChE}$ enzyme in a combination containing no OP. This is seen in all combinations with different concentrations of both metoclopramide and diphenhydramine (Table $r$, Figure r).

\section{Conclusion}

The use of weak ChE inhibitors may reduce the toxicity of strong one OP , but still not to significant degree. The use of a combination of such weak $\mathrm{ChE}$ inhibitor as a protector to reduce the toxicity of strong one (OP) show slightly different way of inhibition and reduction of OP toxicity than when used as alone depending on their different abilities to compete with each other and different affinities to bind the 
enzyme, and this phenomenon differs from one concentration to other for each one of the weak ChE inhibitor.

\section{Acknowledgments}

The study was supported by the College of Pharmacy, University of Mosul, Iraq.

\section{References}

1- Coggon D. Work with pesticides and organophosphate sheep dips. Occup Med, $r \ldots r ; o r: \leqslant T V \leqslant V \cdot$.

$r$ - Wilson BW. Cholinesterase inhibition. In: Wexler $\mathrm{P}$ (ed.). Encyclopedia of Toxicology. Vol. 1 Academic Press, San Diego 1991;rrt_rs.

r- Bajgar J. Organophosphates/nerve agent poisoning: mechanism of action, diagnosis, prophylaxis, and treatment. Adv Clin Chem r.. ¿; rA:101_r17.

¿- Rusyniak DE, Nanagas KA. Organophosphate poisoning. Semin Neurol $Y_{*} \cdot \xi ; Y \leqslant: 19 V_{-} Y_{-} \leqslant$.

○- Wilson BW. Clinical enzymology. In: Loeb WF, Quimby FW (eds.). The clinical chemistry of laboratory animals. Philadelphia, PA: Taylor and Francis $1999 ; r 99$ _ «o .

7. Karanth S, Pope C. In vitro inhibition of blood cholinesterase activities from horse, cow, and rat by tetrachlorvinphos. Int $\mathrm{J}$ Toxicol

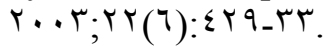

$\checkmark$ - Bird SB, Gaspari RJ, Lee WJ, et al. Diphenhydramine as a protective agent in a rat model of acute, lethal organophosphate poisoning. Acad Emerg Med r.. r;q:1 rqq_ I rVY.

^. Faris GAM, Mohammad FK. Prevention and treatment of dichlorvos-induced toxicosis in mice by diphenhydramine. Vet Hum Toxicol 199v;rq:rr_ro.

9. Yakoub LK, Mohammad FK. .Medetomidine protection against diazinon-induced toxicosis in mice.

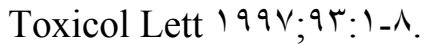

1.- Petroianu GA, Hasan MY, Nurulain SM, Arafat K, Sheen R, Saleh A, Schmitt A.,. Protective drugs in acute large-dose exposure to organophosphates: A com parison of metoclopramidee and tiapride with pralidoxime in rats.

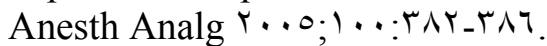

1)- Mahmood AAJ. Interaction of Phenothiazines with Dichlorvos (Cholinesterase Inhibitors) in Vitro Study. M.Sc. Thesis, College of Pharmacy, University of Mosul, Mosul. Y... 0 .

IY. Rang HP, Dale MM, Ritter JM, Moore PK.. Pharmacology. oth ed, Churchill Livingstone, Edinburgh. $r . . r ; r v \leqslant$.

Ir. Petroianu GA, Hasan MY, Kosanovic M, Vijayasarathy C, Saleh AM.,. Metoclopramidee protection of cholinesterase from paraoxon inhibition. Vet Hum Toxicol r..r; $\{0:$ rol-ror.

$1 \leq$ - Al-Zubaidy, MHI. Interaction of metoclopramidee with cholinesterase Inhibitors in chicks. M.Sc. Thesis, College of Veterinary Medicine, University of Mosul, Mosul, Y . . ₹

10. Petroainu, GA, Kuhn,F, Thyes C, et al. In vitro protection of plasma cholinesterases by metoclopramidee from inhibition by paraxon. J. Appl. Toxicol r..r:Tr:VO-Vq.

17. Shinner, HJ, Girling, KJ, Whitehurst A, Nathanson, MH. Influence of metoclopramidee on plasma cholinesterase and duration of action of mivacurium. $\mathrm{Br} J$ Anesth 1999;Ar( $\leqslant): 0 \leqslant r_{-} 0 \leqslant 0$.

IV- BNF. British National Formulary 07, British Medical Association, Royal Pharmaceutical Society of Great Britin. UK Y.. ^.

\^- Laurence DR, Bennett PN, Brown MJ.. Clinical Pharmacology. ${ }^{9}$ th 
ed., Churchill Livingstone, New York r..r;rTV_s. .

19. Potter WZ, Hollister LE. Antihistaminic agents. In. Katzung, BG. (editor). Basic and Clinical Pharmacology. 9th edition, Lange Medical Books / Mc Graw Hill. New York. Y..v;011_.0 ז .

r.- Al-Baggou' B.Kh, Mohammad F. $\mathrm{K}$. Antagonism of methomylinduced toxicosis by diphenhydramine in rats; Environ Toxicol Pharmacol, 1999; $\vee: 119$ _ iro

Y) - Al-Baggou BKh, Mohammad F.K. Effects of histamine $H_{\text {}}$ antagonists on the acute toxicity of physostigmine and neostigmine in mice. Iraqi J Vet. Sci 199^;।।:

rr- Fernandez G, Diaz Gomez MI, et al. Cholinesterase inhibition by phenothiazine antihistaminic: analysis of its postulated toxicity. Toxicol Appl Pharmacol

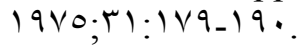

rr- Ahmed OAH, Mohammad FK.,.A simplified eleclrometric technique for rapid measurement of human blood cholinesterase activity.

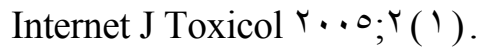

$r \leq-$ Mohammad FK, Alias AS, Ahmed OAH.,. Electrometric measurement of plasma, erythrocyte and whole blood cholinesterase activities in healthy human volunteers. J Med Toxicol r..v;r:ro-r.

ro- Mohammad FK, Faris GA-M, AlKassim NA. A modified electrometric method for measurement of erythrocyte acetylcholinesterase activity in sheep. Vet Hum Toxicol 199v;

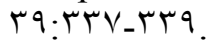

Y. - Bruning JL, Kintaz, BL. Computational Handbook of Statistics. Scott, Foresman and Co., Glenview, Illinois, 19vV:11.

$r V_{-}$Petrie A. Lecture Notes on Medical Statistics. Black Well Scientific Publications, Oxford. 19VA

Y^_ Long PW. Phenothiazine tranquilizers. Internet Mental Health. J Appl Toxicol Y...०; /०(^): $0 .-\mathrm{V}$.

rq- Nasello AG, Gidali, D, Felicio LF. A comparative study of the anticholinestrase activity of several antipsychotic agents. Pharmacol Biochem Behav r...r; $\vee \circ(\varepsilon): \wedge 90_{-}$ 9.1.

r. - Iyaniwura TT. In vitro toxicology of organophosphorus pesticide combinations. In Vitro Toxicol $199 \cdot ; r_{0}:$ rVT-rVV.

r. - WHO. Methomyl. World Health Organization, Geneva 1997; $\vee \leqslant$ VI.

rr- Fikes JD. Organophosphorous and carbamate insecticides. Vet. Clin. North Am: Small Anim. Prac $199 \cdot ; r_{\cdot}$ :rOT_rTV.

r. Somani SM, Dube SN. Physostigmine: An overview as pretreatment drug for organophosphate intoxication. Int. J. Clin Pharmacol Therap

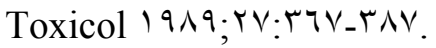

rะ_ Al-Zubaidy MHI, Mohammad FK, Metoclopramidee protection of diazinon-induced toxicosis in chickens J Vet Sci $r \cdots \vee ; \wedge: Y \leqslant १ \_$ ros

ro- Inglis F. The tolerability and safety of cholinesterase inhibitors in the treatment of dementia.Int $\mathrm{J}$ Clin Pract Suppl $r \cdot r_{;} \mid r v_{:} \leqslant 0_{-} T r$. 